\title{
Limb-mammary syndrome
}

INSERM

\section{Source}

INSERM. (1999). Orphanet: an online rare disease and orphan drug data base. Limb-

mammary syndrome. ORPHA:69085

Limb-mammary syndrome (LMS) is a rare disease belonging to the group of ectodermal dysplasias. 